\title{
Chronodisruption and Ambulatory Circadian Monitoring in Cancer Patients: Beyond the Body Clock
}

\author{
Pedro F. Almaida-Pagan 1,2,3 $\cdot$ María Torrente ${ }^{4,5,6}$ (D) Manuel Campos ${ }^{1,2,3} \cdot$ Mariano Provencio $^{4}$. \\ Juan Antonio Madrid ${ }^{1,2,3} \cdot$ Fabio Franco $^{4}$ - Beatriz Rodríguez Morilla ${ }^{1,2,3} \cdot$ Blanca Cantos $^{4}$. Pedro A. Sousa ${ }^{7}$ (1) \\ María José Martínez Madrid ${ }^{1,2,3}$. Joao Pimentao ${ }^{7}$ María Ángeles Rol ${ }^{1,2,3}$
}

Accepted: 16 September 2021 / Published online: 21 January 2022

(c) The Author(s) 2022

\begin{abstract}
Purpose of Review Circadian rhythms impose daily rhythms a remarkable variety of metabolic and physiological functions, such as cell proliferation, inflammation, and DNA damage response. Accumulating epidemiological and genetic evidence indicates that circadian rhythms' disruption may be linked to cancer. The integration of circadian biology into cancer research may offer new options for increasing cancer treatment effectiveness and would encompass the prevention, diagnosis, and treatment of this disease.

Recent Findings In recent years, there has been a significant development and use of multi-modal sensors to monitor physical activity, sleep, and circadian rhythms, allowing, for the very first time, scaling accurate sleep monitoring to epidemiological research linking sleep patterns to disease, and wellness applications providing new potential applications.

Summary This review highlights the role of circadian clock in tumorigenesis, cancer hallmarks and introduces the stateof-the-art in sleep-monitoring technologies, discussing the eventual application of insights in clinical settings and cancer research.
\end{abstract}

Keywords Circadian rhythms · Chronodisruption · Ambulatory circadian monitoring · Cancer patients · Tumorigenesis · Multi-modal sensors

This article is part of the Topical collection on Evolving Therapies

María Torrente

maria.torrente@salud.madrid.org

Kronohealth SL, Murcia, Spain

2 Chronobiology Lab, Department of Physiology, College of Biology, University of Murcia, Mare Nostrum Campus, IUIE, IMIB-Arrixaca, Murcia, Spain

3 Ciber Fragilidad Y Envejecimiento Saludable (CIBERFES), Instituto de Salud Carlos III, Madrid, Spain

4 Servicio de Oncología Médica, Hospital Universitario Puerta de Hierro-Majadahonda, Madrid, Spain

5 Medical Oncology Department, Puerta de Hierro-Majadahonda University Hospital, Calle Manuel de Falla, 1, 28222 Madrid, Spain

6 Faculty of Health Sciences, Francisco de Vitoria University, Madrid, Spain

7 Department of Electrical Engineering, Faculty of Science and Technology, Universidade Nova de Lisboa, Lisbon, Portugal

\section{Introduction: on the Clock}

Recent studies in circadian biology bear Benjamin Franklin, the sage of colonial America, out, on his advice "Early to bed and early to rise, makes a man healthy, wealthy, and wise." Staying in synchrony with the 24-h light-dark cycle of Earth has indeed proven benefits to human health and brain function [1].

Circadian biology studies the biochemical clocks that keep time in our brains and most cells in our bodies. Evidence is accumulating that misalignment of these clocks with the daily light-dark cycle of our environment can have profound impact on physiology, raising the risk of disease. Circadian rhythms control a remarkable variety of metabolic and physiological functions in the human body. Accumulating epidemiological and genetic evidence in the last years indicates that the disruption of circadian rhythms, or chronodisruption (CD), may be directly linked to cancer, due to impairment of cellular functions important for tumor suppression including cell proliferation, senescence, 


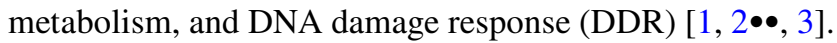
Perturbations of these processes are hallmarks of cancer and chronic circadian rhythm disruption predisposes to tumor development. Indeed, several molecular gears constituting the circadian clock machinery have been found to establish functional interplays with regulators of the cell cycle, and alterations in clock function could lead to aberrant cellular proliferation [4]. In addition, connections between the circadian clock and cellular metabolism, regulated by chromatin remodeling, have been identified, thus suggesting that abnormal metabolism in cancer could also be a consequence of a

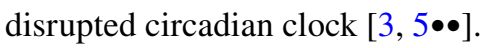

Circadian rhythms are endogenously generated rhythms that occur with a periodicity of approximately $24 \mathrm{~h}$. In humans, as in all animals, circadian rhythms regulate hundreds of activities, from sleep patterns to body temperature, or digestion. The machinery of the molecular clock in mammals, thoroughly described in literature [1,3], is based on auto-regulatory transcriptional feedback loops driven by the heterodimer of transcription factors BMAL1/CLOCK which binds DNA recognition sequences called E-boxes and activates the expression of a wide number of genes (clock-controlled genes or CCGs, representing 3-10\% of all mRNAs expressed in any tissue).

Among all CCGs, the heterodimer BMAL1/CLOCK activates the expression of their downstream transcriptional repressor targets Cryptochrome (Cryl, 2) and Period (Perl, $2,3)$ at the beginning of the circadian day. The accumulation of PER and CRY proteins in the cytoplasm by the end of the circadian day leads to the formation of a PER/CRY repressor complex that translocates into the nucleus at the beginning of the circadian night and inhibits the activity of BMAL1/ CLOCK heterodimers. In addition, there is a second feedback loop by which the transcription of Bmall is alternatively regulated by two of its own transcription targets, the nuclear receptors REV-ERB $\alpha / \beta$ (the repressors) and ROR $\alpha$ (the activator) [6]. The multiple interlocked auto-regulatory feedback loops result in a robust circadian variation in the expression and activity of Bmall over a 24-h period, providing a driving force for circadian oscillation of a wide number of genes, some of which are key regulators of cell proliferation, metabolism, senescence, and DDR.

Although circadian rhythms are autonomously generated at the cell level due to the existence of the molecular clock, these rhythms also respond to an internal time, which is set by a master clock or central pacemaker. In humans, this role is played by the suprachiasmatic nucleus ( $\mathrm{SCN})$, a hypothalamus region that through physical (temperature swings), humoral (melatonin and cortisol), and nervous signals (autonomic nervous system), synchronizes the peripheral clocks. The SCN is inherently sensitive to environmental cues, so-called zeitgebers (German for time-givers). The most powerful zeitgeber is the 24-h light/dark cycle, which resets circadian functions by acting on neurons within the SCN via a direct connection with the melanopsin-expressing ganglion cells in the retina [6]. Therefore, environmental light "sets the time" of the central clock or circadian pacemaker, which in turn synchronizes the billions of peripheral clocks located in every single nucleated cell and drives the expression of key genes for cancer development.

A shift in the synchronizing environmental cues, for example, as a consequence of a flight crossing different time zones, or working night shifts, induces a change in the central clock phase that directly affects the peripheral clocks that reside in various tissues throughout the body [7-9]. If these changes become chronic, something that is happening nowadays as a consequence of modern lifestyle, a separation between our biological time (internal time set by the $\mathrm{SCN}$ ), our habits (social time), and the environmental synchronizers (external time) may take place, which can in turn cause a relevant impairment of the circadian organization of physiology, endocrinology, metabolism, and behavior in the human body. This phenomenon, recently denominated with the term chronodisruption (CD) [10], can manifest as a reduction in the amplitude of circadian rhythms, as a complete asynchrony, an advance, or a delay of the peripheral clocks, compared to the SCN phase or even as a phase inversion of the rhythms [11]. It has been proven that CD is closely linked to chronic processes such as aging and cancer [2 $\bullet \bullet$, $5 \bullet \bullet, 12,13,14 \bullet \bullet, 15,16 \bullet$ ]. Of interesting note, in 2007 (and revised in 2019), the International Agency for Research on Cancer (IARC) from the World Health Organization (WHO) classified the "shift-work that involves circadian disruption," which includes both working at night and working in a job that involves rapidly crossing many time zones, as probably carcinogenic to humans [17].

\section{Circadian System Status in Cancer Patients}

Alterations caused by cancer itself or by anti-cancer therapy at cell and/or tissue levels may disrupt CS functioning [18, 19]. Cancer, or the organism response to stress caused by cancer, leads to an increased release of pro-inflammatory cytokines that affect the hypothalamus-pituitary-adrenal axis and cause CS deregulation [20]. Impairment of CS correlates to several symptoms in cancer patients, such as reduced capability to cope with daily-life activities, insomnia, appetite loss, and fatigue, all of them diminishing quality of life (QoL) [19, 21-25].

Alternatively, several studies in humans have evidenced that CD may not only be a consequence of tumor development, but also may cause cancer and promote its progression. This has been particularly shown in metastatic colorectal cancer [26-29], in advanced breast cancer [24, 30-36], and in lung cancer [21,37-39]. Besides, circadian rhythm 
dysfunction is also linked to lower anti-cancer treatment efficacy and, overall, to reduce survival [22, 23, 27, 29, 31].

\section{Chronodisruption as Cause of Cancer}

Erren and Reiter [10] proposed that CD may play a critical role in the expression and development of disease through two related ways: firstly, as a possible cause of chronic disease by representing the adverse split of a physiological nexus of internal and external times, and secondly, by being a critical link in the chain of causation leading to chronic disease, including cancer [40], via a relevant disturbance of the circadian organization of physiology, endocrinology, metabolism, and behavior.

In this sense, we can define chronodisruptors as exogenous and endogenous "exposures" or "effectors" which are chronobiologically active and can thus disrupt the timing and order, i.e., temporal organization of physiologic functions and hierarchies. In principle, whatever allows the establishment of temporal organizational order in organisms should also be capable of disrupting such order or temporal program when present, or applied in excess or deficit and, most importantly, at unusual and inappropriate times, especially when combined with further agonistic or antagonistic chronobiological effectors [41]. An endogenous chronodisruptor may be a mutation in a clock gene or the alteration in cell signaling as a consequence of tumor development. In this case, the tumor is able to impact the molecular clock functioning and cause $\mathrm{CD}$.

Alternatively, one key exogenous or external chronodisruptor is light at night (LAN). Light, when received at unusual times, can powerfully disrupt the circadian rhythmicity of our biology, thus leading to $\mathrm{CD}$ and to an increase in the risk of developing certain diseases. In this case, CD would happen independently of the tumor and would be a risk factor for its genesis and progression. Epidemiologic studies have shown that LAN may contribute to higher breast cancer rates in women with normal sight [42-44], while the opposite occurs in visually impaired women who are insensitive to light changes in the environment, and thus depend largely on free-running endogenous circadian clocks to synchronize daily physiology $[45,46]$. Several studies suggest that totally blind women are half as likely to have breast cancer as women who are not totally blind [46]. Thus, further research is needed in order to elucidate the impact on $\mathrm{CD}$ in these blind patients and how these factors may relate to breast cancer risk. Besides, working night shifts and/or flying frequently across different time zones may also be associated to increased risk of developing many forms of cancer [47], and melatonin suppression and/or disruption of its adequate timing under chronodisruptive conditions may be an important factor for increasing cancer risk [47-49].
Other exogenous effectors, such as our daily eating time schedule [50] or physical activity [51], that contribute to synchronize peripheral clocks (along with the light/dark cycle), can also be disruptors when performed at inadequate times.

\section{How to Assess CD: Ambulatory Circadian Monitoring}

Recently, several prestigious scientific journals have published about health risks produced by inadequate exposure to synchronizers [52-54] and the need to foster the development and validation of "wearable" devices, m-Health applications, and instruments suitable for population-based and big data approaches to develop predictive models and biomarker platforms for assessing circadian health $[55,56]$. As a matter of fact, measuring CD is still an unresolved challenge, especially under free-living conditions. Of note, it has been proposed as a bona fide public health issue in light of the very substantial number of individuals involved [57]. The development of wearable multisensorized devices (i.e., electronic health records) and procedures to accurately quantify sleep and $\mathrm{CD}$, both in clinical and nonclinical environments, is key for personalized medicine through unhealthy habit detection and assisting in the diagnose and treatment of diseases.

Furthermore, the workshop on "Developing Biomarker Arrays Predicting Sleep and Circadian-Coupled Risks to Health" jointly sponsored by the National Heart Lung and Blood Institute, National Institute on Aging, and the Sleep Research Society specifically identified the "gaps" to implement potentially high-yield strategies in biomarker research that can be summarized in Table 1 [55].

Due to its location in the brain, human SCN function or its responses to light can only be indirectly assessed by the so-called circadian marker rhythms [73]. Ambulatory multivariable recordings were for the first time proposed by our group [73, 74] (Fig. 1).

Sensor implementation in wearable devices (i.e., wrist watch-like) allows ACM to combine measurements of (a) endogenous variables, such as skin temperature [75]; (b) zeitnehmers (German word meaning timekeeper), such as motor activity and body position more dependent on willingness [76]; and (c) exogenous synchronizers or zeitgebers, such as light exposure and environmental temperature, providing information about lifestyle and the bidirectional crosstalk between internal time and external synchronizers [77-79], which is paramount to determine a subject suffering from CD [10]. If the environmental time (given by the light/ dark cycle mainly), the internal time (marked endogenously and autonomously by the SCN), and the social time (given by the external interval for work or social activities) are in 
Table 1 ACM for circadian system status in cancer patients: state of the art

\begin{tabular}{|c|c|c|c|c|c|}
\hline Cancer type & Stage & Results & Study & ACM method & Rhythms analyzed \\
\hline \multirow[t]{14}{*}{ Breast cancer } & \multirow[t]{2}{*}{ General } & $\begin{array}{l}\text { Circadian rhythm disrup- } \\
\text { tion is involved in the } \\
\text { experience of fatigue } \\
\text { and depression in cancer } \\
\text { patients }\end{array}$ & {$[58]$} & Wrist actigraphy & RAR/SWR \\
\hline & & $\begin{array}{l}\text { Significant relationships } \\
\text { between subjective and } \\
\text { objective sleep, but no } \\
\text { consistent patterns }\end{array}$ & {$[59]$} & Wrist actigraphy & RAR/SWR \\
\hline & \multirow[t]{7}{*}{ Before CT } & Disturbed sleep and fatigue & {$[24]$} & Wrist actigraphy & RAR/SWR \\
\hline & & $\begin{array}{l}\text { Short sleep time and long } \\
\text { naps }\end{array}$ & {$[33]$} & Wrist actigraphy & SWR \\
\hline & & $\begin{array}{l}\text { High number and length of } \\
\text { night awakenings }\end{array}$ & [59] & Wrist actigraphy & RAR/SWR \\
\hline & & Low mean daytime activity & & & \\
\hline & & RAR disrupted & {$[59,60]$} & Wrist actigraphy & RAR/SWR \\
\hline & & $\begin{array}{l}\text { Patients with more delayed } \\
\text { rhythms experience more } \\
\text { daily dysfunction second- } \\
\text { ary to fatigue }\end{array}$ & {$[24]$} & Wrist actigraphy & RAR/SWR \\
\hline & & $\begin{array}{l}\text { Less recorded nap time } \\
\text { correlated with physical } \\
\text { component scale of the } \\
\text { medical outcomes study } \\
\text { 36-item short form }\end{array}$ & {$[33]$} & Wrist actigraphy & SWR \\
\hline & \multirow[t]{2}{*}{ During CT } & $\begin{array}{l}\text { SWR impaired during the } \\
\text { first week of both CT } \\
\text { cycles } 1 \text { and } 4\end{array}$ & [36] & Wrist actigraphy & SWR \\
\hline & & $\begin{array}{l}\text { RAR parameters decreased } \\
\text { with the increasing num- } \\
\text { ber of CT cycles }\end{array}$ & {$[30,31,60]$} & Wrist actigraphy & RAR/SWR \\
\hline & After CT & $\begin{array}{l}\text { Altered RAR parameters at } \\
5 \text { years after the primary } \\
\text { diagnosis }\end{array}$ & {$[32]$} & Wrist actigraphy & RAR \\
\hline & In-patients & $\begin{array}{l}\text { The hospitalization exac- } \\
\text { erbated the problems } \\
\text { associated with RAR }\end{array}$ & {$[31]$} & Wrist actigraphy & RAR \\
\hline & Melatonin & $\begin{array}{l}\text { Bedtime melatonin } \\
\text { improved sleep quality, } \\
\text { sleep fragmentation, and } \\
\text { quantity }\end{array}$ & {$[61]$} & Wrist actigraphy & RAR/SWR \\
\hline
\end{tabular}


Table 1 (continued)

\begin{tabular}{|c|c|c|c|c|c|}
\hline Cancer type & Stage & Results & Study & ACM method & Rhythms analyzed \\
\hline \multirow[t]{8}{*}{ Lung cancer } & \multirow[t]{3}{*}{ Before CT } & Poor SWR before treatment & {$[38]$} & Wrist actigraphy & SWR \\
\hline & & $\begin{array}{l}\text { Lower sleep efficiency and } \\
\text { higher sleep fragmenta- } \\
\text { tion during the night }\end{array}$ & {$[62]$} & Wrist actigraphy & RAR/SWR \\
\hline & & $\begin{array}{l}\text { Lower mean activity during } \\
\text { the day }\end{array}$ & & & \\
\hline & \multirow[t]{5}{*}{ During CT } & $\begin{array}{l}\text { Disturbed RAR/SWR in } \\
\text { cancer patients }\end{array}$ & {$[21,39,63]$} & Wrist actigraphy & RAR/SWR \\
\hline & & $\begin{array}{l}\text { Circadian disruption } \\
\text { selectively affects specific } \\
\text { quality of life domains }\end{array}$ & {$[21]$} & Wrist actigraphy & RAR/SWR \\
\hline & & $\begin{array}{l}\text { CD correlated with poor } \\
\text { QoL and function }\end{array}$ & {$[39,63]$} & Wrist actigraphy & RAR/SWR \\
\hline & & $\begin{array}{l}\text { Cancer symptoms had a } \\
\text { stronger association with } \\
\text { sleep than mood }\end{array}$ & [39] & Wrist actigraphy & SWR \\
\hline & & $\begin{array}{l}\text { SWR improves at week } 48 \\
\text { after start of treatment }\end{array}$ & [38] & Wrist actigraphy & SWR \\
\hline \multirow[t]{10}{*}{ Colorectal cancer } & \multirow[t]{2}{*}{ General } & $\begin{array}{l}\text { An unstable RAR associ- } \\
\text { ates to lower QoL and } \\
\text { survival }\end{array}$ & {$[22,26]$} & Wrist actigraphy & RAR \\
\hline & & $\begin{array}{l}\text { RAR associated with serum } \\
\text { levels of TGF-alpha, } \\
\text { IL-6, cortisol, and tumor- } \\
\text { related symptoms }\end{array}$ & {$[64]$} & Wrist actigraphy & RAR \\
\hline & \multirow[t]{2}{*}{ Before CT } & $\begin{array}{l}\text { RAR disruption before } \\
\text { treatment. RAR is good } \\
\text { predictor of overall sur- } \\
\text { vival and progression-free } \\
\text { survival }\end{array}$ & {$[65]$} & Wrist actigraphy & RAR \\
\hline & & $\begin{array}{l}\text { CD in 52\% patients: lower } \\
\text { median activity counts, } \\
\text { worse fragmented sleep, } \\
\text { and an abnormal tempera- } \\
\text { ture rhythm }\end{array}$ & {$[66]$} & Chest sensor & Chest skin temp and activity \\
\hline & \multirow[t]{6}{*}{ During CT } & $\begin{array}{l}\text { RAR correlated with global } \\
\text { QoL, physical function- } \\
\text { ing, social functioning, } \\
\text { fatigue, and appetite loss }\end{array}$ & \multirow[t]{2}{*}{ [23] } & \multirow[t]{2}{*}{ Wrist actigraphy } & \multirow[t]{2}{*}{ RAR } \\
\hline & & $\begin{array}{l}\text { RAR independently pre- } \\
\text { dicted for overall survival } \\
\text { (OA) }\end{array}$ & & & \\
\hline & & $\begin{array}{l}\mathrm{CD} \text { in } 51 \% \text { patients on } \mathrm{CT} \text {. } \\
\text { Associated to shorter } \mathrm{OA}\end{array}$ & \multirow[t]{2}{*}[27]{} & \multirow[t]{2}{*}{ Wrist actigraphy } & \multirow[t]{2}{*}{ RAR } \\
\hline & & $\begin{array}{l}\text { Higher survival in patients } \\
\text { with a robust RAR }\end{array}$ & & & \\
\hline & & $\begin{array}{l}\text { RAR CD associated } \\
\text { with severe fatigue and } \\
\text { anorexia }\end{array}$ & \multirow[t]{2}{*}{ [29] } & \multirow[t]{2}{*}{ Wrist actigraphy } & \multirow[t]{2}{*}{ RAR } \\
\hline & & $\begin{array}{l}\text { Interference with physical } \\
\text { and social functioning }\end{array}$ & & & \\
\hline
\end{tabular}


Table 1 (continued)

\begin{tabular}{|c|c|c|c|c|c|}
\hline Cancer type & Stage & Results & Study & ACM method & Rhythms analyzed \\
\hline \multirow[t]{3}{*}{ Gastro-intestinal cancer } & During CT & $\begin{array}{l}\text { Three circadian rhythms } \\
\text { and the TAP rhythm } \\
\text { grew less stable and more } \\
\text { fragmented in response } \\
\text { to CT }\end{array}$ & {$[61]$} & Inner wrist surface temp & DST \\
\hline & & \multicolumn{2}{|c|}{$\begin{array}{l}\text { Large inter- and intra-individual changes } \\
\text { were found for T, A, P, and TAP, with } \\
\text { phase differences of up to } 12 \mathrm{~h} \text { among } \\
\text { patients }\end{array}$} & Arm activity & Activity \\
\hline & & \multicolumn{2}{|l|}{$\begin{array}{l}\text { A moderate perturbation of } \\
\text { temporal internal order } \\
\text { was observed }\end{array}$} & Arm position & Position \\
\hline $\begin{array}{l}\text { Breast and gynecologic } \\
\text { cancers }\end{array}$ & After CT & $\begin{array}{l}\text { Systematic bright light } \\
\text { exposure in the morn- } \\
\text { ing may have ben- } \\
\text { eficial effects on sleep in } \\
\text { fatigued cancer survivors }\end{array}$ & {$[67]$} & Wrist actigraphy & SWR \\
\hline \multirow[t]{8}{*}{ Non-cancer specific } & During CT & $\begin{array}{l}\text { Disruptions in skin tem- } \\
\text { perature rhythms }\end{array}$ & {$[68]$} & $\begin{array}{l}\text { Skin surface temperature } \\
\text { patches }\end{array}$ & CBT \\
\hline & During CT & $\begin{array}{l}\text { Circadian patterns in skin } \\
\text { surface temperature and } \\
\text { RAR persisted or were } \\
\text { amplified during and after } \\
\text { CT in 50\% patients }\end{array}$ & [69] & $\begin{array}{l}\text { Skin surface temperature } \\
\text { patches }\end{array}$ & CBT \\
\hline & & $\begin{array}{l}\text { In contrast, transient or sus- } \\
\text { tained disruption of these } \\
\text { biomarkers was found for } \\
\text { the remaining } 50 \%\end{array}$ & & Wrist actigraphy & RAR \\
\hline & & \multicolumn{2}{|c|}{$\begin{array}{l}\text { Large inter-patient differences in cir- } \\
\text { cadian amplitudes and acrophases of } \\
\text { skin surface temperature despite rather } \\
\text { similar RAR acrophases }\end{array}$} & & \\
\hline & During CT & RAR disruption & [70] & Wrist actigraphy & RAR \\
\hline & During CT & $\begin{array}{l}\text { Hospitalization alters RAR } \\
\text { parameters markedly and } \\
\text { deteriorates QoL }\end{array}$ & [71] & Wrist actigraphy & RAR \\
\hline & During CT & $\begin{array}{l}\text { Correlation between ques- } \\
\text { tionnaires (subjective) } \\
\text { and actigraphy (objective) } \\
\text { to estimate sleep }\end{array}$ & [72] & Wrist actigraphy & SWR \\
\hline & & $\begin{array}{l}\text { Awakenings during the } \\
\text { sleep period (estimated } \\
\text { through ACM) best cor- } \\
\text { related with subjective } \\
\text { sleep complaints }\end{array}$ & & & \\
\hline
\end{tabular}

Abbreviations: $A C M$, ambulatory circadian monitoring; $C B T$, core body temperature; $C D$, chronodisruption; $C T$, chemotherapy; $D S T$, distal skin temperature; $I L$, interleukin; $P C S$, physical component scale; $Q o L$, quality of life; $R A R$, rest-activity rhythm; $S F-36$, medical outcomes study 36-item short form health survey; $S W R$, sleep-wake rhythm; $T A P$, temperature, activity, and position integrated variable; $T G F$, transforming growth factor

phase, we should not expect CD. The same will be anticipated when the appropriate phase relationship among overt rhythms (sleep, temperature, activity, etc.) is maintained.

ACM has been validated for sleep-wake detection (it shows higher sensitivity and specificity than actigraphy alone) compared to sleep diaries [73] and polysomnography
(PSG) [74] and it can be used instead of DLMO (dim light melatonin onset) to predict the internal phase [80]. Besides, we have proven its usefulness in very different populations, such as night-shift workers [81, 82], babies [83, 84], hypertensive patients and patients with metabolic syndrome [85, 86], elderly population $[84,87]$, patients with mild cognitive 
Fig. 1 Ambulatory circadian monitoring (ACM) for chronodisruption (CD) detection. ACM, thanks to several sensor implementation in wearable devices (i.e., wristwatch-like), combines measurements of (a) endogenous variables, such as distal skin temperature; (b) zeitnehmers, such as motor activity and body position more dependent on willingness; and (c) exogenous synchronizers, such as light exposure and environmental temperature, providing information about lifestyle and the bidirectional crosstalk between internal time and external synchronizers, which is paramount to determine a subject exposure to $\mathrm{CD}$.

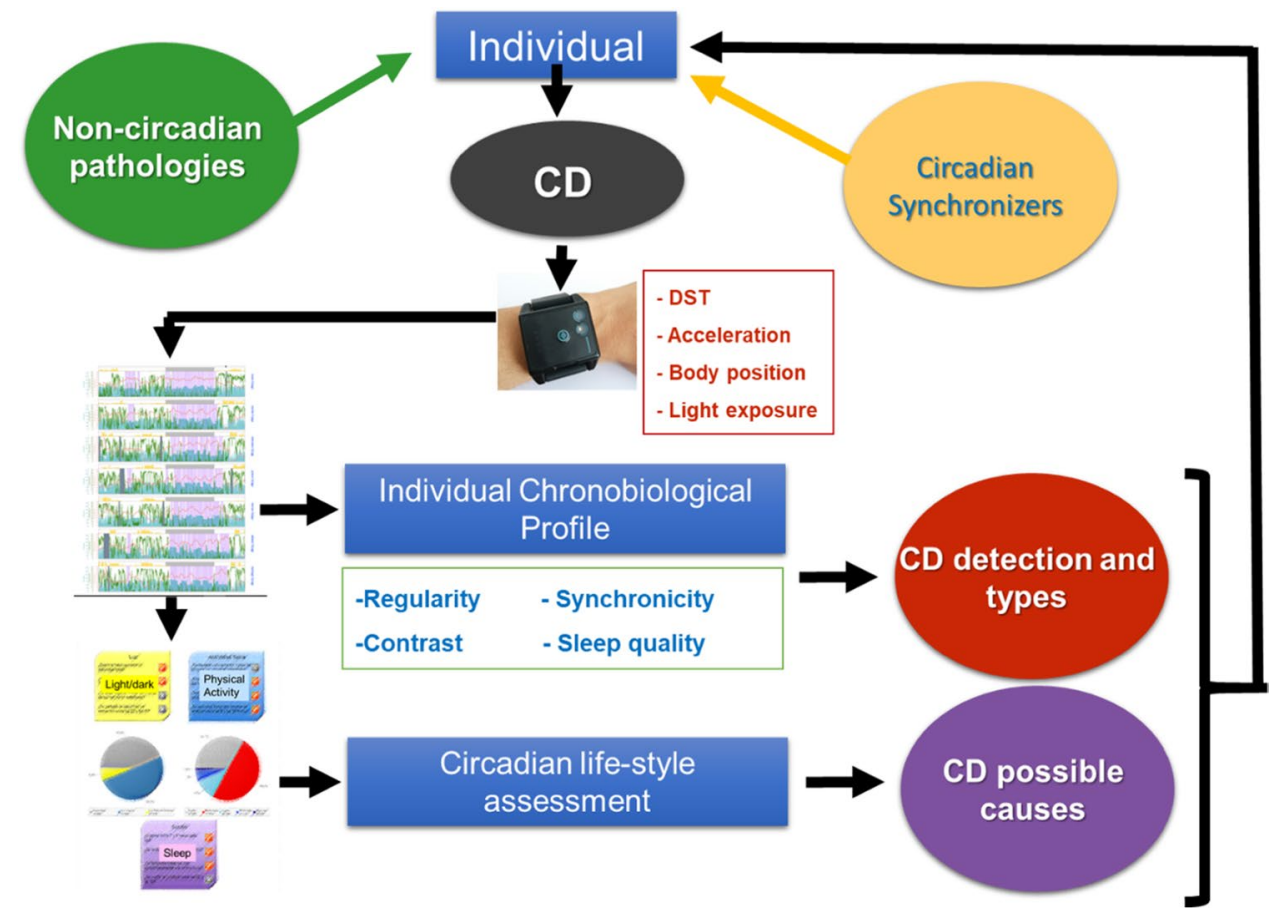

impairment [88], or more recently in patients with sleepdisordered breathing [89], Parkinson's disease [90, 91•], and cancer [61] (Table 1).

Therefore, this wearable technology opens the possibility to study, on a long-term basis, a wide range of patients under real-time conditions and thus providing, at the same time, information on a single individual that can then be used to guide health-related decisions.

\section{ACM for Circadian System Status Assessment in Cancer Patients: State of the Art}

\section{Rest/Activity Rhythm}

Rest/activity rhythm (RAR) is one of the most used biomarkers of CS functioning in cancer patients [92], as it can be non-invasively recorded for long periods by using a wristworn actigraphy sensor and is compatible with oncological treatments (Table 1).

In 2000, Mormont et al. [26] evaluated, in metastatic colorectal cancer patients, the predictive power of circadian rhythms' robustness (an index of rhythm's amplitude) over the patients' prognosis. The subjects' RAR was an independent prognostic factor for cancer patient's survival (patients with poor circadian rhythmicity had a fivefold higher risk of dying within 2 years than patients with a better circadian rhythmicity) and tumor response as well as a quantitative indicator of QoL, better than other overt circadian rhythms such as plasma cortisol or leucocyte count. Since then, several oncological studies have shown that cancer patients exhibit a disruption of RAR before treatment $[65,71,93]$ that worsens with chemotherapy [31, 36, 58, 94].

An unstable RAR associates to sleep impairment and insomnia [59, 63] and a subsequent decrease in QoL [22], which may negatively impact survival in cancer patients [23, 26, 65, 95]. Cancer patients' RAR also experience a deterioration in robustness, which may be used, along with the rhythm stability, in future studies to illustrate clinicians as a potential prognostic factor [26, 62-64].

\section{Sleep/Wake Rhythm}

Prevalence of sleeping disorders in modern society is continuously increasing (it affects up to $40-50 \%$ of the global population) [96], and this elevated incidence is enhanced in cancer patients (up to 60\%). Cancer patients report sleeping disorders before, during, and after treatment, and usually persist in the long term [36, 63, 95, 97, 98]. Furthermore, low sleep quality is commonly associated with fatigue, psychological effects, such as anxiety or depression [62, 99, $100]$, revealing what has been called a cluster of cancer symptoms [24]. These symptoms interact with each other and can negatively impact the patient's QoL, treatment efficacy, and survival [101].

Brzezinski determined that tumors alter existing rhythms and reset the SCN, which causes changes in the sleep/wake rhythm (SWR) [102]. Alternatively, one of the main causes of fatigue experienced by cancer patients during treatment, apart from the direct effects caused by cancer treatment 
itself, is related to the pro-inflammatory cytokine network activity. Cytokines rise inflammatory responses in the central nervous system (CNS), disrupt the hypothalamus-pituitary-adrenal axis and, consequently, the sleep/wake rhythm $[27,103,104]$. This affects SWR regularity and results in increased fatigue, insomnia, or depression caused by several SCN response mechanisms [64, 105]. Besides, severe physical symptoms (i.e., nocturia, dyspnea, or cough) have been reported in lung cancer patients under treatment who experience SWR disruption [106] and several studies indicate that a sleep/wake disruption may even increase the risk of death in cancer patients [22, 26, 27].

Liu et al. [33], based on Berger et al. [59] conclusions, remarked the need to perform longitudinal studies analyzing the relationship between sleep and health-related QoL (HQ-QoL) in cancer patients through objective methods for sleep assessment (Table 1). Komarzynski et al. compared sleep quality estimations from subjective methods (through questionnaires MDSAI (M.D. Anderson Symptom Inventory) and PROM (patient-reported outcome measures)) and from ACM (actigraphy) in advanced stage cancer patients undergoing chemotherapy, and observing that awakenings during the sleep period (estimated through ACM) correlated with subjective sleeping disorders complaints [72]. Therefore, the lower the number of night awakenings the best subjective sleep quality.

Frequent night awakenings or fragmented sleep not only impact negatively the subjective perception of sleep quality, but may also correlate with an altered innate immune function [107], lower natural killer cell count, and reduced survival [34]. Alternatively, a prolonged nocturnal sleep improves QoL, while longer sleep latencies and sleep interruptions worsen it [39]. Besides, a sleep efficiency (\% real time of sleep related to total time in bed) lower than $85 \%$ is independently associated with lower survival in advanced breast cancer patients [108].

Chang and Lin analyzed changes on SWR, sleep quality, anxiety, depression, fatigue, and QoL caused before, during, and after treatment in lung cancer patients [38]. Results showed low SWR robustness before treatment. Compared to basal values, SWR significantly improved in week 48 after beginning the treatment, and anxiety significantly improved in weeks $6,12,24$, and 40 after. In contrast, fatigue exacerbated in weeks 8 and 48 . Furthermore, QoL significantly improved from week 6 until the end of treatment. QoL was negatively affected by poor sleep quality and depression symptoms while was positively impacted by a regular SWR.

Although sleep impairment and fatigue experienced by cancer patients are generally believed to be iatrogenic, partly caused by the psychological impact and the physiological consequences of anti-cancer treatments, further evidence is needed to determine its possible effect on tumorigenesis activation [109, 110]. In 2016, Erren and colleagues performed a meta-analysis of sleep and cancer incidence among more than 1,500,000 subjects from 13 countries and, although they failed to find a clear answer to the question of how cancer and sleep are connected in humans, authors concluded that a complex chronobiological relationship, presumably multidirectional, is plausible [111].

Garland et al. [112] suggested that a perturbation in sleep continuity associates to, or is consequence of, an already initiated disease and, as such, can represent a sign of yet-tobe-diagnosed tumors. It is known that night sleep enhances the immune system against any infection [107, 113]. A lack of sleep induces lower levels of pro-inflammatory cytokines $[114,115]$. Nevertheless, sleep loss also activates the sympathetic nervous system (SNS) and, after a sleep disruption, the excess of adrenergic activity is believed to promote proinflammatory genes expression leading to increased diurnal levels of innate immunity and inflammation markers. There is a growing body of evidence pointing to inflammation as a key factor in cancer incidence and recurrence [107].

\section{Body Position and Temperature}

In general, actigraphy has proved to be very sensitive for detecting sleep, but its ability to detect wake states during the night (specificity) is not so high $[116,117]$. Actigraphy tends to overestimate sleep, as it considers motionless moments as sleep. That is the reason why it loses clinical importance when studying specific pathologies like insomnia, in which the subject lies awake for long periods with almost no movement $[118,119]$. Furthermore, the movements of a bed partner, vehicle vibrations, and sensor removal can all affect the measurement reliability [120].

To counteract the inaccuracy associated to the use of one single variable, multivariable recordings under ambulatory conditions have recently been proposed to assess alterations of the circadian system and sleep [73, 121] (Table 1). These ACM procedures integrate a combination of variables, such as temperature, activity, and body position, which provide complementary information about the CS functionality.

Core body temperature (CBT) follows a circadian pattern which is generated by the $\mathrm{SCN}$ and thus, apart from reflecting the pacemaker function, provides relevant information about the inner phase and amplitude $[61,73,78,122]$. Besides, CBT acts as an effector involved in the internal coordination of peripheral clocks, so as in clock-controlled signaling pathways in tumors $[75,120]$. Based upon this knowledge, several authors point to body temperature monitoring as an appropriate indicator to personalize anti-cancer treatments [68]. However, its evaluation is not problem-free: the CBT rhythm can be determined using a rectal probe connected to an external recorder $[122,123]$ (a system that is neither safe nor convenient for ambulatory assessment of rhythms in cancer patients) or telemetric pills (which are 
very expensive and provide records that are too short) [61]. In 2008, Sarabia et al. showed that peripheral temperature rhythm, determined by a wireless data logger attached to the inner side of the wrist, was a robust rhythm with a pattern that is almost identically reverse to that of CBT [75]. Evidence suggests that sleepiness may be more closely linked to increased distal skin temperature (DST) than to a decrease in CBT [124, 125]. In fact, wrist temperature alone can discriminate between wake and sleep with high specificity and sensitivity and even between phases $1+2$ and 3 [126], although it fails to identify sleep interruptions when they are too short. To date, DST has been used to evaluate circadian rhythms under several physiological and pathological conditions, such as newborn circadian maturation [127], mild cognitive impairment [74], metabolic syndrome and obesity [86] among others; and a correlation has been found with clock gene polymorphisms [128]. Furthermore, DST is highly correlated to the DLMO, considered to be the most robust circadian phase marker [80]. However, although peripheral temperature rhythm has been shown to exhibit a strong endogenous component, due to a relevant genetic influence [77, 129], it is subjected to environmental and physiological influences, including physical activity, body position, high environmental temperatures, and sleep itself [75, 130-132].

In 2010, the Chronobiology Lab from the University of Murcia (Spain) developed an integrated variable called TAP (Temperature, Activity, body Position), which is based on MCA-provided information of DST, motor activity, and body position rhythms. The overall aim of creating this integrated variable was to avoid problems related to masking (that is, the influence of external signals that affect or mask overt rhythms) in the recoding of single variables and thus to allow for a better assessment of the CS functioning [73]. Integrated variable TAP was validated as a useful tool for circadian patterns classification according to robustness. Body position, when the sensor is appropriately positioned, helps to depict daily habits and permits distinguishing when the subject is lying down or sitting (for example, at a computer), in spite of low activity levels in both cases [73]. Besides, integration of body position and motor activity to DST allows to identify sleep interruptions and to calculate several reliable sleep parameters, such as total time of sleep or sleep efficiency [73].

TAP algorithm has demonstrated its usefulness for RAR evaluation [80] and its values correlated very well with sleep logs from PSG, the "gold-standard" of sleep studies [74]. Results from Ortiz-Tudela et al. [74] show that integrated variable TAP is the most sensitive and specific to discriminate sleep from wakefulness and has higher coincidence rates with PSG than any other published actigraphy measurements [73, 116, 117]. Moreover, the simultaneous recording of multiple overt rhythms allows us to assess their internal synchrony, constituting a first approach to evaluate whether temporal order is maintained.

Finally, Ortiz-Tudela et al. [61] showed for the first time that the circadian system presents a huge variability in terms of phase distribution (12-h spread among subjects) in cancer patients and more importantly, a moderately perturbed internal temporal order. This study corroborated what previous research in cancer patients had shown: the existence of a perturbed RAR even before chemotherapy, which is negatively impacted by treatment $[24,36,60,70]$.

\section{Light Exposure}

The use of light sensors as part of ACM allows to record environmental light exposure (intensity and spectrum) during $24 \mathrm{~h}$ and gives additional information to characterize the subjects' life habits with no need of sleep diaries. Recently, Madrid-Navarro et al. [91•] integrated visible light exposure into the new variable TAPL (temperature, activity, position, and light), a modification of the TAP algorithm [73], for automatic detection of sleep and wake periods in Parkinson's patients.

After a polysomnographic validation of sleep detection by ACM, TAPL was proven to be a useful tool for evaluating, while subjects develop their normal life, the main sleep parameters: time in bed, total sleep time, sleep efficiency, and wake after sleep onset (WASO), without the need to resort to different specific algorithms for each sleep pathology or age group [91•].

\section{Chronotherapy and Cancer: Past, Current, and Future Approaches to Cancer Treatment}

Since the discovery of the biological clock, cancer treatments are administered at the appropriate time-of-day, according to biological rhythms. This way, chronotherapy has been shown to improve cancer treatment efficacy [133]. In the last two decades, different experimental and clinical studies have reported positive associations between the circadian clock and drug response in cancer patients, while others have reported a negative correlation between chronodisruption during and/or after cancer treatment with survival rate in cancer animal models and patients [134]. These findings suggest a role of the circadian clock in the outcome of cancer progression and treatment response, specifically in mechanisms of resistance to chemotherapy, controlled by the circadian clock [135-137], which regulates fundamental processes in the cell, often targeted machinery of cytotoxic anticancer drugs, as well as modulating the absorption, metabolism, and elimination of these drugs. Of note, several clinical studies have shown that adverse effects experienced by cancer patients treated with cisplatin-based chemotherapy decreases when applied in a chronomodulated 
context $[138,139]$, thus proving that chronomodulated drug administration provides the potential to optimize the dosage of drugs and duration of treatments to efficiently eliminate cancer cells while reducing adverse effects and prevent early drug resistance. Also, downregulation of core clock gene Per2 in tumors predicted poor survival in chemo-naive patients with metastatic colorectal cancer. This was the first report of an association between clock gene downregulation and outcome in any cancer [140]. In rectal cancer, a prospective single-arm phase II with capecitabine and radiotherapy treatment in 85 patients with oral administration of capecitabine (60\% dose at 8 am and $40 \%$ dose at noon) obtained a total tumor regression in $20 \%$ of patients, with no grade IV toxicities reported [141]. Another study on advanced non-small cell lung carcinoma randomized 41 patients with cisplatin administration at $6 \mathrm{pm}$ or at 6 am vs routine chemotherapy. Lower gastrointestinal toxicity $(p<0.05)$ and higher clearance for cisplatin administered at $6 \mathrm{pm}(p<0.05)$ were observed in the chronotherapy group [138]. Two clinical trials compared the toxicity of two dosing times of anthracyclines and cisplatin in patients with advanced ovarian cancer. Both randomized studies demonstrated that doxorubicin or theprubicin when administered around 6 am and cisplatin between 4 and $8 \mathrm{pm}$ produced significantly fewer severe hematologic suppression and renal toxicity than when given $12 \mathrm{~h}$ earlier, respectively [142].

Although the clinical relevance of chronopharmacology principles in cancer is gradually maturing with the application of clinical big data [143], in vitro pharmacology, mobile platforms and apps [144], and mathematical modeling [145] to help expand our knowledge of the molecular clock and its relevance to human disease, some challenging issues facing chronotherapeutic approaches still remain to be highlighted (such as how a given cancer affects the clock and vice versa, how a given oncotherapy and other factors, such as our lifestyle and environment (personal chronotypes), affect the clock). This is probably due to variability of individual biological rhythms.

Therefore, optimizing the timing of drugs with a narrow therapeutic index and significant circadian fluctuation could lead to significant clinical benefit from improvements in efficacy and minimization of toxicity [146, 147]. The conception of novel anticancer drug delivery systems and the combination with chronobiology may provide a powerful tool to optimize cancer therapy and represents a new challenge to improve the quality of life and survival of cancer patients through personalized cancer chronotherapeutics.

\section{Conclusions}

Although the results of many epidemiologic and animal studies are consistent with a role for the circadian clock in the genesis and progression of tumors, available data are still insufficient to conclude that clock disruption is generally carcinogenic. Nevertheless, both experimental and clinical data support the relevance of sleep and circadian rhythm disruption, or $\mathrm{CD}$, in the expression and development of cancer. Besides, CD correlates with poor QoL and function. ACM, through wearable technology, opens the possibility to assess $\mathrm{CD}$ in cancer patients on a long-term basis, under real-time conditions, and provides, at the same time, objective information on a single individual that can then be used to guide health-related decisions.

ACM based on multi-variable recording continuously assesses circadian biomarkers, such as those provided by the rest/activity, body position, distal skin temperature, and light exposure monitoring computed in the integrated variable TAPL, and constitutes a unique tool to apply big-data analysis and design successful interventions in cancer patients, taking into account the status and phase of individual circadian systems. The great inter-patient variability at baseline, during and after treatment, and the differing profound effects of chemotherapy on circadian robustness, phase, and internal order synchronization confirm the interest of such multiparametric evaluation of cancer outpatients.

The useful information provided by this concomitant TAPL monitoring is also relevant for interventional studies targeting the circadian timing system, in order to enhance or protect its function, with the aim of improving the wellbeing and outcomes of cancer patients. In this sense, ACM allows for an integrated analysis of the internal, external, and social times of the individual and thus helps to design individualized strategies to revert $\mathrm{CD}$, first considering life habits (timing and regularity of bright light exposure, physical exercise, work duties, social and family life, sleep/wake routine, fasting/feeding schedule...), before addressing pharmacological approaches.

Thus, there is a certain biological plausibility that needs to be verified and studied, which could relate CD alterations and their impact on mechanisms and evolution of cancer. The objectivity that new technologies (wearables) can provide in their study needs to be further implemented in controlled and well-designed clinical trials in order to clarify and help to understand this relation. Likewise, it will be necessary to delve into the molecular mechanisms that may relate $\mathrm{CD}$ and tumorigenesis, especially in light of new treatments such as immunotherapy, where the tumor microenvironment is a determinant factor in the response. Future hypothesis-driven and discovery-oriented research should focus on specific interactions between clock components and carcinogenic mechanisms to realize the full clinical potential of the relationship between clocks and cancer.

Funding This work was supported in part by CLARIFY project, within European Union's Horizon 2020 Research and Innovation Programme 
under grant agreement No. 875160, Instituto de Fomento de la Región de Murcia (INFO) and the European Regional Development Fund (FEDER).

The contents in this article are those of the authors and do not necessarily reflect the official opinion of the European Union. Neither the European Union institutions and bodies nor any person acting on their behalf may be held responsible for the use, which may be made of the information contained therein.

\section{Declarations}

Conflict of Interest The authors declare no competing interests.

Open Access This article is licensed under a Creative Commons Attribution 4.0 International License, which permits use, sharing, adaptation, distribution and reproduction in any medium or format, as long as you give appropriate credit to the original author(s) and the source, provide a link to the Creative Commons licence, and indicate if changes were made. The images or other third party material in this article are included in the article's Creative Commons licence, unless indicated otherwise in a credit line to the material. If material is not included in the article's Creative Commons licence and your intended use is not permitted by statutory regulation or exceeds the permitted use, you will need to obtain permission directly from the copyright holder. To view a copy of this licence, visit http://creativecommons.org/licenses/by/4.0/.

\section{References}

Papers of particular interest, published recently, have been highlighted as:

- Of importance

$\bullet$ Of major importance

1. Fu L, Kettner NM. The circadian clock in cancer development and therapy. Prog Mol Biol Transl Sci. 2013;119:221-82.

2.• Kinouchi K, Sassone-Corsi P. Metabolic rivalry: circadian homeostasis and tumorigenesis. Nat. Rev. Cancer. 2020. page 645-61. This review outlines recent discoveries of the interplay between circadian rhythms, proliferative metabolism, and cancer, highlighting potential opportunities in the development of future therapeutic strategies.

3. Sahar S, Sassone-Corsi P. Metabolism and cancer: the circadian clock connection. Nat Rev Cancer. 2009;9:886-96.

4. Hunt T, Sassone-Corsi P. Riding tandem: circadian clocks and the cell cycle. Cell. 2007;129:461-4.

5.• Masri S, Sassone-Corsi P. The emerging link between cancer, metabolism and circadian rhythms. Nat Med. 2018;24:1795803. This review highlights the emerging links between cancer metabolism and the circadian clock and discusses the possible design of chronopharmacological strategies.

6. Cho H, Zhao X, Hatori M, Yu RT, Barish GD, Lam MT, et al. Regulation of circadian behaviour and metabolism by REVERBalpha and REV-ERB-beta. Nature. 2012;485:123-7.

7. Do MTH, Yau K-W. Intrinsically photosensitive retinal ganglion cells. Physiol Rev. 2010;90:1547-81.

8. Davidson AJ, Castanon-Cervantes O, Leise TL, Molyneux PC, Marrington ME. Visualizing jet lag in the mouse suprachiasmatic nucleus and peripheral circadian timing system. Eur J Neurosci. 2009;29:171-80.

9. Golombek DA, Rosenstein RE. Physiology of circadian entrainment. Physiol Rev. 2010;90:1063-102.
10. Erren TC, Reiter RJ. Revisiting chronodisruption: when the physiological nexus between internal and external times splits in humans. Naturwissenschaften. 2013;100:291-8.

11. Kohyama J. Neurochemical and neuropharmacological aspects of circadian disruptions: an introduction to asynchronization. Curr Neuropharmacol. 2011;9:330-41.

12. Innominato PF, Roche VP, Palesh OG, Ulusakarya A, Spiegel D, Lévi FA. The circadian timing system in clinical oncology. Ann Med. 2014;46:191-207.

13. Morgan MN, Dvuchbabny S, Martinez C-A, Kerr B, Cistulli PA, Cook KM. The cancer clock is (not) ticking: links between circadian rhythms and cancer. Clocks\&Sleep. 2019;1:435-58.

14. $\bullet$ Shafi AA, Knudsen KE. Cancer and the circadian clock. Cancer Res. 2019;79:3806-14. This review highlights the importance of developing a deeper understanding of circadian-cancer regulation for developing new strategies for cancer interception, prevention, and management.

15. Sulli G, Lam MTY, Panda S. Interplay between circadian clock and cancer: new frontiers for cancer treatment. Trends in Cancer. 2019;5:475-94.

16. Tsuchiya Y, Umemura Y, Yagita K. Circadian clock and cancer: from a viewpoint of cellular differentiation. Int J Urol. 2020;27:518-24. This review describes how further insights on circadian function could lead to the identification of biomarkers for cancer diagnosis and prognosis, as well as novel targets for treatment.

17. International Agency for Research on Cancer (WHO). IARC monographs on the identification of carcinogenic hazards to humans. IARC Monogr Meet 124 Night Shift Work (4-11 June 2019). 2019;124:1-4

18. Mohawk JA, Green CB, Takahashi J. Central and peripheral circadian clocks in mammals. Annu Rev Neurosci. 2012;35:445-62.

19. Innominato PF, Levi FA, Bjarnason G. Chronotherapy and the molecular clock: clinical implications in oncology. Adv Drug Deliv Rev. 2010;62:979-1001.

20. Kim HJ, Barsevick AM, Fang CY, Miaskowski C. Common biological pathways underlying the psychoneurological symptom cluster in cancer patients. Cancer Nurs. 2012;35:1-20.

21. Grutsch JF, Ferrans C, Wood PA, Du-Quiton J, Quiton DFT, Reynolds JL, et al. The association of quality of life with potentially remediable disruptions of circadian sleep/activity rhythms in patients with advanced lung cancer. BMC Cancer. 2011;11:193.

22. Mormont MC, Waterhouse J. Contribution of the rest-activity circadian rhythm to quality of life in cancer patients. Chronobiol Int. 2002;19:313-23.

23. Innominato PF, Focan C, Gorlia T, Moreau T, Garufi C, Waterhouse J, et al. Circadian rhythm in rest and activity: a biological correlate of quality of life and a predictor of survival in patients with metastatic colorectal cancer. Cancer Res. 2009;69:4700-7.

24. Ancoli-Israel S, Liu L, Marler MR, Parker BA. Fatigue, sleep, and circadian rhythms prior to chemotherapy for breast cancer. Support Care Cancer. 2006;14:201-9.

25. Sephton S, Spiegel D. Circadian disruption in cancer: a neuroendocrine-immune pathway from stress to disease? Brain Behav Immun. 2003;17:321-8.

26. Mormont MC, Waterhouse J, Bleuzen P, Giacchetti S, Jami A, Bogdan A, et al. Marked 24-h rest/activity rhythms are associated with better quality of life, better response, and longer survival in patients with metastatic colorectal cancer and good performance status. Clin Cancer Res. 2000;6:3038-45.

27. Innominato PF, Giacchetti S, Bjarnason GA, Focan C, Garufi $\mathrm{C}$, Coudert B, et al. Prediction of overall survival through circadian rest-activity monitoring during chemotherapy for metastatic colorectal cancer. Int J Cancer. 2012;131:2684-92. 
28. Innominato PF, Giacchetti S, Moreau T, Bjarnason GA, Smaaland R, Focan C, et al. Fatigue and weight loss predict survival on circadian chemotherapy for metastatic colorectal cancer. Cancer. 2013;119:2564-73.

29. Innominato PF, Komarzynski S, Palesh OG, Dallmann R, Bjarnason GA, Giacchetti S, et al. Circadian rest-activity rhythm as an objective biomarker of patient-reported outcomes in patients with advanced cancer. Cancer Med. 2018;7:4396-405.

30. Sultan A, Choudhary V, Parganiha A. Worsening of rest-activity circadian rhythm and quality of life in female breast cancer patients along progression of chemotherapy cycles. Chronobiol Int. 2017;34:609-23.

31. Sultan A, Pati AK, Choudhary V, Parganiha A. Hospitalizationinduced exacerbation of the ill effects of chemotherapy on restactivity rhythm and quality of life of breast cancer patients: a prospective and comparative cross-sectional follow-up study. Chronobiol Int. 2018;35:1513-32.

32. Roveda E, Bruno E, Galasso L, Mulè A, Castelli L, Villarini A, et al. Rest-activity circadian rhythm in breast cancer survivors at 5 years after the primary diagnosis. Chronobiol Int. 2019;36:1156-65.

33. Liu L, Fiorentino L, Rissling M, Natarajan L, Parker BA, Dimsdale JE, et al. Decreased health-related quality of life in women with breast cancer is associated with poor sleep. Behav Sleep Med. 2013;11:189-206.

34. Sephton SE, Sapolsky RM, Kraemer HC, Spiegel D. Diurnal cortisol rhythm as a predictor of breast cancer survival. J Natl Cancer Inst. 2000;92:994-1000.

35. Innominato PF, Lim AS, Palesh O, Clemons M, Trudeau M, Eisen A, et al. The effect of melatonin on sleep and quality of life in patients with advanced breast cancer. Support Care Cancer. 2016;24:1097-105.

36. Savard J, Liu L, Natarajan L, Rissling MB, Neikrug AB, He $\mathrm{F}$, et al. Breast cancer patients have progressively impaired sleep-wake activity rhythms during chemotherapy. Sleep. 2009;32:1155-60.

37. Sephton SE, Lush E, Dedert EA, Floyd AR, Rebholz WN, Dhabhar FS, et al. Diurnal cortisol rhythm as a predictor of lung cancer survival. Brain Behav Immun. 2013;30:S163-70.

38. Chang WP, Lin CC. Changes in the sleep-wake rhythm, sleep quality, mood, and quality of life of patients receiving treatment for lung cancer: a longitudinal study. Chronobiol Int. 2017;34:451-61.

39. Dean GE, Redeker NS, Wang YJ, Rogers AE, Dickerson SS, Steinbrenner LM, et al. Sleep, mood, and quality of life in patients receiving treatment for lung cancer. Oncol Nurs Forum. 2013;40:441-51.

40. Evans JA, Davidson AJ. Health consequences of circadian disruption in humans and animal models. Prog. Mol. Biol. Transl. Sci. 2013

41. Erren TC, Reiter RJ. Defining chronodisruption. J Pineal Res. 2009;46:245-7.

42. Kloog I, Stevens RG, Haim A, Portnov BA. Nighttime light level co-distributes with breast cancer incidence worldwide. Cancer Causes Control. 2010;21:2059-68.

43. Stevens RG. Light-at-night, circadian disruption and breast cancer: assessment of existing evidence. Int $\mathrm{J}$ Epidemiol. 2009;38:963-70

44. Costa G, Haus E, Stevens R. Shift work and cancer-considerations on rationale, mechanisms, and epidemiology. Scand J Work Env Heal. 2010;36:163-79.

45. Kliukiene J, Tynes T, Andersen A. Risk of breast cancer among Norwegian women with visual impairment. Br J Cancer. 2001;84:397-9.
46. Hahn RA. Profound bilateral blindness and the incidence of breast cancer. Epidemiology. 1991;2:208-10.

47. Haus EL, Smolensky MH. Shift work and cancer risk: potential mechanistic roles of circadian disruption, light at night, and sleep deprivation. Sleep Med Rev. 2013;17:273-84.

48. Blask DE, Brainard GC, Dauchy RT, Hanifin JP, Davidson LK, Krause JA, et al. Melatonin-depleted blood from premenopausal women exposed to light at night stimulates growth of human breast cancer xenografts in nude rats. Cancer Res. 2005;65:11174-84.

49. Blask DE, Dauchy RT, Sauer LA, Krause JA, Brainard JC. Light during darkness, melatonin suppression and cancer progression. Neuro Endocrinol Lett. 2002;2:52-6.

50. Kogevinas M, Espinosa A, Castelló A, Gómez-Acebo I, Guevara M, Martin V, et al. Effect of mistimed eating patterns on breast and prostate cancer risk (MCC-Spain Study). Int J Cancer. 2018;143:2380-9.

51. Weitzer J, Castaño-Vinyals G, Aragonés N, Gómez-Acebo I, Guevara M, Amiano P, et al. Effect of time of day of recreational and household physical activity on prostate and breast cancer risk (MCC-Spain Study) . Int J Cancer. 2020;1-12.

52. Czeisler CA. Perspective: casting light on sleep deficiency. Nature. 2013;497:S13.

53. Kantermann T. Circadian biology: sleep-styles shaped by lightstyles. Curr Biol. 2013;23:R689-90.

54. Mehta R, Zhu R. Blue or red? Exploring the effect of color on cognitive task performances. Science (80-). 2009;323:1226-9.

55. Mullington JM, Abbott SM, Carroll JE, Davis CJ, Dijk D-J, Dinges DF, et al. Developing biomarker arrays predicting sleep and circadian-coupled risks to health. Sleep. 2016;39:727-36.

56. Li X, Dunn J, Salins D, Zhou G, Zhou W, Schüssler-Fiorenza Rose SM, et al. Digital health: tracking physiomes and activity using wearable biosensors reveals useful health-related information. PLoS Biol. 2017;15:1-30.

57. Touitou Y, Reinberg A, Touitou D. Association between light at night, melatonin secretion, sleep deprivation, and the internal clock: health impacts and mechanisms of circadian disruption. Life Sci. 2017;173:94-106.

58. Roscoe J, Morrow G, Hickok J, Bushunow P, Matteson S, Rakita $\mathrm{D}$, et al. Temporal interrelationships among fatigue, circadian rhythm and depression in breast cancer patients undergoing chemotherapy treatment. Support Care Cancer. 2002;10:329-36.

59. Berger AM, Farr LA, Kuhn BR, Fischer P, Agrawal S. Values of sleep/wake, activity/rest, circadian rhythms, and fatigue prior to adjuvant breast cancer chemotherapy. J Pain Symptom Manag. 2007;33:398-9.

60. Berger AM, Wielgus K, Hertzog M, Fischer P, Farr L. Patterns of circadian activity rhythms and their relationships with fatigue and anxiety/depression in women treated with breast cancer adjuvant chemotherapy. Support Care Cancer. 2010;18:105-14.

61. Ortiz-Tudela E, Innominato PF, Rol MA, Lévi F, Madrid JA. Relevance of internal time and circadian robustness for cancer patients. BMC Cancer. 2016;16:285

62. Le Guen Y, Gagnadoux F, Hureaux J, Jeanfaivre T, Meslier N, Racineux J-L, et al. Sleep disturbances and impaired daytime functioning in outpatients with newly diagnosed lung cancer. Lung Cancer. 2007;58:139-43.

63. Levin RD, Daehler MA, Grutsch JF, Quiton J, Lis CG, Peterson C, Gupta D, Watson K, Layer D, Huff-Adams S, et al. Circadian function in patients with advanced non-small-cell lung cancer. Br J Cancer. 2005;93:1202-8.

64. Rich T, Innominato P, Boerner J, Mormont M, Iacobelli S, Baron $\mathrm{B}$, et al. Elevated serum cytokines correlated with altered behavior, serum cortisol rhythm, and dampened 24-hour rest-activity 
patterns in patients with metastatic colorectal cancer. Clin Cancer Res. 2005;11:1757-64.

65. Lévi FA, Dugue P-A, Innominato PF, Karabaué A, Dispersyn G, Parganiha A, et al. Wrist actimetry circadian rhythm as a robust predictor of colorectal cancer patients survival. Chronobiol Int. 2014;31:891-900.

66. Lévi F, Komarzynski S, Huang Q, Young T, Ang Y, Fuller C, et al. Tele-monitoring of cancer patients' rhythms during daily life identifies actionable determinants of circadian and sleep disruption. Cancers (Basel). 2020;12:1938.

67. Wu LM, Amidi A, Valdimarsdottir H, Ancoli-Israel S, Liu L, Winke G, et al. The effect of systematic light exposure on sleep in a mixed group of fatigued cancer survivors. J Clin Sleep Med. 2018;14:31-9.

68. Scully CG, Karaboué A, Liu WM, Meyer J, Innominato PF, Chon KH, et al. Skin surface temperature rhythms as potential circadian biomarkers for personalized chronotherapeutics in cancer patients. Interface Focus. 2011;1:48-60.

69. Roche VP, Mohamad-Djafari A, Innominato PF, Karaboué A, Gorbach A, Lévi FA. Thoracic surface temperature rhythms as circadian biomarkers for cancer chronotherapy. Chronobiol Int. 2014;31:409-20.

70. Ortiz-Tudela E, Iurisci I, Beau J, Karaboue A, Moreau T, Rol MA, et al. The circadian rest-activity rhythm, a potential safety pharmacology endpoint of cancer chemotherapy. Int J Cancer. 2014; 134:2717-25.

71. Parganiha A, Taj S, Chandel P, Sultan A, Choudhary V. Effect of hospitalization on rest-activity rhythm and quality of life of cancer patients. IJEB. 2014;52:549-58.

72. Komarzynski S, Huang Q, Levi FA, Palesh OG, Ulusakarya A, Bouchahda M, et al. The day after: correlates of patient-reported outcomes with actigraphy-assessed sleep in cancer patients at home (inCASA project). Sleep. 2019;42:1-12.

73. Ortiz-Tudela E, Martinez-Nicolas A, Campos M, Rol MÁ, Madrid JA. A new integrated variable based on thermometry, actimetry and body position (TAP) to evaluate circadian system status in humans. PLoS Comput Biol. 2010;6:e1000996.

74. Ortiz-Tudela E, Martinez-Nicolas A, Albares J, Segarra F, Campos M, Estivill E, et al. Ambulatory circadian monitoring (ACM) based on thermometry, motor activity and body position (TAP): a comparison with polysomnography. Physiol Behav. 2014;126:30-8.

75. Sarabia JA, Rol MA, Mendiola P, Madrid JA. Circadian rhythm of wrist temperature in normal-living subjects. A candidate of new index of the circadian system. Physiol Behav. 2008;95:570-80.

76. Skeldon AC, Phillips AJK, Dijk DJ. The effects of self-selected light-dark cycles and social constraints on human sleep and circadian timing: a modeling approach. Sci Rep. 2017;7:1-14.

77. Martinez-Nicolas A, Ortiz-Tudela E, Rol MA, Madrid JA. Uncovering different masking factors on wrist skin temperature rhythm in free-living subjects. PLoS One. 2013;8:e61142.

78. Martinez-Nicolas A, Ortiz-Tudela E, Madrid JA, Rol M. Crosstalk between environmental light and internal time in humans. Chronobiol Int. 2011;28:617-29.

79. Martinez-Nicolas A, Madrid JA, Rol MA. Day-night contrast as source of health for the human circadian system. Chronobiol Int. 2014;31:382-93.

80. Bonmati-Carrion MA, Middleton B, Revell V, Skene DJ, Rol MA, Madrid JA. Circadian phase assessment by ambulatory monitoring in humans: correlation with dim light melatonin onset. Chronobiol Int. 2014;31:37-51.

81. Moreno-Casbas MT, Ruzafa-Martinez M, Rol MA, Madrid JA, Serrano Pinto A, Gonzalez-Maria E, et al. Sleepiness in Spanish nursing staff - influence of chronotype and care unit in circadian rhythm impairment: research protocol. J Adv Nurs. 2014;70:211-9.

82. Gomez-Garcia T, Ruzafa-Martinez M, Fuentelsaz-Gallego C, Madrid JA, Rol MA, Martinez-Madrid MJ, et al. Nurses' sleep quality, work environment and quality of care in the Spanish National Health System: observational study among different shifts. BMJ Open. 2016;6:1-11.

83. Zornoza-Moreno M, Fuentes-Hernández S, Prieto-Sánchez MT, Blanco JE, Pagán A, Rol MÁ, et al. Influence of gestational diabetes on circadian rhythms of children and their association with fetal adiposity. Diabetes Metab Res Rev. 2013;29:483-91.

84. Batinga H, Martinez-Nicolas A, Zornoza-Moreno M, SánchezSolis M, Larqué E, Mondéjar MT, et al. Ontogeny and aging of the distal skin temperature rhythm in humans. Age. 2015;37:29.

85. Blazquez A, Martinez-Nicolas A, Salazar FJ, Rol MA, Madrid JA. Wrist skin temperature, motor activity, and body position as determinants of the circadian pattern of blood pressure. Chronobiol Int. 2012;29:747-56.

86. Corbalán-Tutau MD, Madrid JA, Ordovás JM, Smith CE, Nicolás F, Garaulet M. Differences in daily rhythms of wrist temperature between obese and normal-weight women: associations with metabolic syndrome features. Chronobiol Int. 2011;28:425-33.

87. Martinez-Nicolas A, Madrid JA, García FJ, Campos M, MorenoCasbas MT, Almaida-Pagán PF, et al. Circadian monitoring as an aging predictor. Sci Rep. 2018;8:1-11.

88. Ortiz-Tudela E, Martinez-Nicolas A, Díaz-Mardomingo C, García-Herranz S, Pereda-Pérez I, Valencia A, et al. The characterization of biological rhythms in mild cognitive impairment. Biomed Res Int. 2014;2014:1-7.

89. Martinez-Nicolas A, Guaita M, Santamaría J, Montserrat JM, Rol MA, Madrid J. Circadian impairment of distal skin temperature rhythm in patients with sleep-disordered breathing: the effect of CPAP. Sleep. 2017;40:zsx067.

90. Madrid-Navarro CJ, Escamilla-Sevilla F, Mínguez-Castellanos A, Campos M, Ruiz-Abellán F, Madrid JA, et al. Multidimensional circadian monitoring by wearable biosensors in Parkinson's disease. Front Neurol. 2018;9:1-14.

91. Madrid-Navarro CJ, Puertas Cuesta FJ, Escamilla-Sevilla F, Campos M, Ruiz Abellán F, Rol MA, et al. Validation of a device for the ambulatory monitoring of sleep patterns: a pilot study on Parkinson's disease. Front Neurol. 2019;10:356. This article validates an ambulatory circadian monitoring device clinically useful to evaluate sleep in an objective manner and apply it to the evaluation of sleep quality in patients with Parkinson disease.

92. Ancoli-Israel S, Cole R, Alessi C, Chambers M, Moorcroft W, Pollack CP. The role of actigraphy in the study of sleep and circadian rhythms. Sleep. 2003;26:342-92.

93. Taj S, Choudhary V, Parganiha A. Temporal profiles of physical activity and energy expenditure in cancer inpatients. Biol Rhythm Res. 2013;44:219-35.

94. Lévi F, Okyar A, Dulong S, Innominato PF, Clairambault J. Circadian timing in cancer treatments. Annu Rev Pharmacol Toxicol. 2010;50:377-421.

95. Palesh O, Peppone L, Innominato PF, Janelsins M, Jeong M, Sprod L, et al. Prevalence, putative mechanisms, and current management of sleep problems during chemotherapy for cancer. Nat Sci Sleep. 2012;4:151-62.

96. Léger D, Poursain B, Neubauer D, Uchiyama M. An international survey of sleeping problems in the general population. Curr Med Res Opin. 2008;24:307-17.

97. Garland SN, Johnson JA, Savard J, Gehrman P, Perlis M, Carlson $\mathrm{L}$, et al. Sleeping well with cancer: a systematic review of cognitive behavioral therapy for insomnia in cancer patients. Neuropsychiatr Dis Treat. 2014;10:1113-24. 
98. Ortiz-Tudela E. Crosstalk between sleep disturbances and cancer survival. Sleep Med. 2015;16:315-6.

99. Block KI, Hrushesky W, Blask D. In this issue: circadian disruption and cancer. Integr Cancer Ther. 2009;8:295-7.

100. Mills PJ, Dimsdale J. Sleep apnea: a model for studying cytokines, sleep, and sleep disruption. Brain Behav Immun. 2004;18:298-303.

101. Miller A, Ancoli-Israel S, Bower J, Capuron L, Irwin MR. Neuroendocrine-immune mechanisms of behavioral comorbidities in patients with cancer. J Clin Oncol. 2008;26:971-82.

102. Brzezinski A. Melatonin in humans. N Engl J Med. 1997;336:186-95.

103. Bower J, Ganz P, Irwin M, Kwan L, Breen E, Cole S. Inflammation and behavioral symptoms after breast cancer treatment: do fatigue, depression, and sleep disturbance share a common underlying mechanism? J Clin Oncol. 2011;29:3517-22.

104. Collado-Hidalgo A, Bower J, Ganz P, Irwin MR, Cole S. Cytokine gene polymorphisms and fatigue in breast cancer survivors: early findings. Brain Behav Immun. 2008;22:1197-200.

105. Clevenger L, Schrepf A, Degeest K, Bender D, Goodheart M, Ahmed A, et al. Sleep disturbance, distress, and quality of life in ovarian cancer patients during the first year after diagnosis. Cancer. 2013;119:3234-41.

106. Vena C, Parker K, Allen R, Bliwise D, Jain S, Kimble L. Sleepwake disturbances and quality of life in patients with advanced lung cancer. Oncol Nurs Forum. 2006;33:761-9.

107. Irwin M, Opp M. Sleep health: reciprocal regulation of sleep and innate immunity. Neuropsychopharmacology. 2017;42:129-55.

108. Palesh O, Aldridge-Gerry A, Zeitzer J, Koopman C, Neri E, Giese-Davis J, et al. Actigraphy-measured sleep disruption as a predictor of survival among women with advanced breast cancer. Sleep. 2014;37:837-42.

109. Uth K, Sleigh R. Deregulation of the circadian clock constitutes a significant factor in tumorigenesis: a clockwork cancer. Part I: clocks and clocking machinery. Biotechnol Biotechnol Equip. 2014;28:176-83.

110. Uth K, Sleigh R. Deregulation of the circadian clock constitutes a significant factor in tumorigenesis: a clockwork cancer. Part II. In vivo studies. Biotechnol Biotechnol Equip. 2014;28:379-86.

111. Erren T, Morfeld P, Foster R, Reiter R, Groß J, Westermann IK. Sleep and cancer: synthesis of experimental data and metaanalyses of cancer incidence among some 1,500,000 study individuals in 13 countries. Chronobiol Int. 2016;33:325-50.

112. Garland SN, Irwin MR, Posner D, Perlis ML. Are sleep continuity disturbance and fatigue prodromal symptoms of cancer development? Med Hypotheses. 2018;120:72-5.

113. Irwin MR. Why sleep is important for health: a psychoneuroimmunology perspective. Annu Rev Psychol. 2015;66:143-72.

114. Besedovsky L, Lange T, Born J. Sleep and immune function. Pflugers Arch. 2012;463:121-37.

115. Redwine L, Hauger RL, Gillin JC, Irwin M. Effects of sleep and sleep deprivation on interleukin-6, growth hormone, cortisol, and melatonin levels in humans. J Clin Endocrinol Metab. 2000;85:3597-603.

116. Meltzer LJ, Walsh CM, Traylor J, Westin A. Direct comparison of two new actigraphs and polysomnography in children and adolescents. Sleep. 2012;35:159-66.

117. Jean-Louis G, Kripke DF, Cole RJ, Assmus JD, Langer R. Sleep detection with an accelerometer actigraph: comparisons with polysomnography. Physiol Behav. 2001;72:21-8.

118. Paquet J, Kawinska A, Carrier J. Wake detection capacity of actigraphy during sleep. Sleep. 2007;30:1362-9.

119. Acebo C, LeBourgeois M. Actigraphy. Respir Care Clin N Am. 2006;12:23-30.

120. Sadeh A, Acebo C. The role of actigraphy in sleep medicine. Sleep Med Rev. 2002;6:113-24.
121. Kolodyazhniy V, Späti J, Frey S, Götz T, Wirz-Justice A, Kräuchi K, et al. Estimation of human circadian phase via a multichannel ambulatory monitoring system and a multiple regression model. J Biol Rhythms. 2011;26:55-67.

122. Waterhouse J, Drust B, Weinert D, Edwards B, Gregson W, Atkinson G, et al. The circadian rhythm of core temperature: origin and some implications for exercise performance. Chronobiol Int. 2005;22:207-25.

123. Kräuchi K. How is the circadian rhythm of core body temperature regulated? Clin Aut Res. 2002;12:147-9.

124. Kräuchi K, Cajochen C, Wirz-Justice A. Thermophysiologic aspects of the three-process-model of sleepiness regulation. Clin Sport Med. 2005;24:287-300.

125. Van Someren E. Sleep propensity is modulated by circadian and behavior-induced changes in cutaneous temperature. J Therm Biol. 2004;29:437-44.

126. Montgomery SM, Sirota A, Buzsaki G. Theta and gamma coordination of hippocampal networks during waking and rapid eye movement sleep. J Neurosci. 2008;28:6731-41.

127. Zornoza-Moreno M, Fuentes-Hernández S, Sánchez-Solis M, Rol MÁ, Larqué E, Madrid JA. Assessment of circadian rhythms of both skin temperature and motor activity in infants during the first 6 months of life. Chronobiol Int. 2011;28:330-7.

128. Bandín-Saura MC, Martinez-Nicolas A, Ordovás JM, Ros Lucas JA, Castell P, Silvente T, et al. Differences in circadian rhythmicity in CLOCK $3111 \mathrm{~T} / \mathrm{C}$ genetic variants in moderate obese women as assessed by thermometry, actimetry and body position (TAP). Int J Obes. 2012;37:1044-50.

129. Lopez-Minguez J, Ordonana JR, Sanchez-Romera JF, Madrid JA, Garaulet M. Circadian system heritability as assessed by wrist temperature: a twin study. Chronobiol Int. 2015;2015(32):71-80.

130. Kräuchi K. The human sleep-wake cycle reconsidered from a thermoregulatory point of view. Physiol Behav. 2007;90:236-45.

131. Reilly T, Waterhouse J. Circadian aspects of body temperature regulation in exercise. J Therm Biol. 2009;34:161-70.

132. Wakamura T, Tokura H. Circadian rhythm of rectal temperature in humans under different ambient temperature cycles. J Therm Biol. 2002;27:439-47.

133. Albuquerque T, Neves AR, Quintela T, Costa D. Exploring the link between chronobiology and drug delivery: effects on cancer therapy. J Mol Med (Berl). 2021 Jul 2. https://doi.org/10.1007/ s00109-021-02106-x. Epub ahead of print. PMID: 34213595.

134. Kuo Tia Tyrsett, Ladurner Andreas G. Exploiting the circadian clock for improved cancer therapy: perspective from a cell biologist. Frontiers in Genetics, 2019; (10), 1210.

135. Allada R, Bass J. Circadian mechanisms in medicine. N Engl J Med. 2021;384:550-61. https://doi.org/10.1056/NEJMra1802 337.

136. Dallmann R, Brown SA, Gachon F. Chronopharmacology: new insights and therapeutic implications. Annu Rev Pharmacol Toxicol. 2014;54(1):339-61.

137. Dallmann R, Okyar A, Lévi F. Dosing-time makes the poison: circadian regulation and pharmacotherapy. Trends Mol Med. 2016;22(5):430-45.

138. Li J, Chen R, Ji M, Zou SL, Zhu LN. Cisplatin-based chronotherapy for advanced non-small cell lung cancer patients: a randomized controlled study and its pharmacokinetics analysis. Cancer Chemother Pharmacol. 2015;76:651-5.

139. Zhang PX, Jin F, Li ZL, Wu WL, Li YY, Long JH. A randomized phase II trial of induction chemotherapy followed by cisplatin chronotherapy versus constant rate delivery combined with radiotherapy. Chronobiol Int. 2017;35(2):240-8. https://doi. org/10.1080/07420528.2017.1397684.

140. Placobelli S, Innominato P, Piantelli M, Bjarnason GA, Coudert B, Focan C, Giacchetti S, Poncet A, Garufi C, Lévi F. Tumor 
clock protein PER2 as a determinant of survival in patients (pts) receiving oxaliplatin-5-FU-leucovorin as first-line chemotherapy for metastatic colorectal cancer (MCC). J Clin Oncol. 2008;26:11032-11032.

141. Akgun Z, Saglam S, Yucel S, Gural Z, Balik E, Cipe G, Yildiz S, Kilickap S, Okyar A, Kaytan-Saglam E. Neoadjuvant chronomodulated capecitabine with radiotherapy in rectal cancer: a phase II brunch regimen study. Cancer Chemother Pharmacol. 2014;74:751-6.

142. Lévi F, Focan C, Karaboué A, de la Valette V, Focan-Henrard D, Baron B, Kreutz F, Giacchetti S. Implications of circadian clocks for the rhythmic delivery of cancer therapeutics. Adv Drug Deliv Rev. 2007 Aug 31;59(9-10):1015-35. https://doi.org/10.1016/j. addr.2006.11.001 (Epub 2007 Jul 4 PMID: 17692427).

143. Singh G, Schulthess D, Hughes N, Vannieuwenhuyse B, Kalra D. Real world big data for clinical research and drug development. Drug Discovery Today. 2018;23(3):652-60. https://doi.org/10. 1016/j.drudis.2017.12.002.

144. Komarzynski S, Huang Q, Innominato PF, Maurice M, Arbaud A, Beau J. Relevance of a mobile internet platform for capturing inter- and intrasubject variabilities in circadian coordination during daily routine: pilot study. J Med Internet Res. 2018;20(6):e204-18. https://doi.org/10.2196/jmir.9779.

145. Dulong S, Ballesta A, Okyar A, Lévi F. Identification of circadian determinants of cancer chronotherapy through in vitro chronopharmacology and mathematical modeling. Mol Cancer Ther. 2015;14(9):2154-64. https://doi.org/10.1158/1535-7163. MCT-15-0129.

146. Lee Y, Fong SY, Shon J, Zhang SL, Brooks R, Lahens NF, Chen D, Dang CV, Field JM, Sehgal A. Time-of-day specificity of anticancer drugs may be mediated by circadian regulation of the cell cycle. Sci Adv. 2021;7(7):eabd2645.
147. McKenna H, van der Horst GTJ, Reiss I, et al. Clinical chronobiology: a timely consideration in critical care medicine. Crit Care. 2018;22:124. https://doi.org/10.1186/s13054-018-2041-x.

148. Terzibasi-Tozzini E, Martinez-Nicolas A, Lucas-Sánchez A. The clock is ticking. Ageing of the circadian system: from physiology to cell cycle. Semin Cell Dev Biol. 2017;70:164-76.

149. Ko YJ, Kwon YM, Kim KH, Choi HC, Chun SH, Al E. Highsensitivity C-reactive protein levels and cancer mortality. Cancer Epidemiol Biomarkers Prev. 2012;21:2076-86.

150. Baune BT, Rothermundt M, Ladwig KH, Meisinger C, Berger K. Systemic inflammation (interleukin 6) predicts all-cause mortality in men: results from a 9-year follow-up of the MEMO study. Age. 2011;33:209-17.

151. Touvier M, Fezeu L, Ahluwalia N, Julia C, Charnaux N, Sutton A, et al. Association between prediagnostic biomarkers of inflammation and endothelial function and cancer risk: a nested case-control study. Am J Epidemiol. 2013;177:3-13.

152. Cole SW. Chronic inflammation and breast cancer recurrence. J Clin Oncol. 2009;27:3418-9.

153. Pierce BL, Ballard-Barbash R, Bernstein L, Baumgartner RN, Neuhouser ML, Wener MH, et al. Elevated biomarkers of inflammation are associated with reduced survival among breast cancer patients. J Clin Oncol. 2009;27:3437-44.

154. Mantovani A, Allavena P, Sica A, Balkwill F. Cancer-related inflammation. Nature. 2008;454:436-44.

Publisher's Note Springer Nature remains neutral with regard to jurisdictional claims in published maps and institutional affiliations. 